ISSN:

Print - 2277-078X

Online - $2315-747 \mathrm{X}$

(c) FUNAAB 2018

Joumal of

Humanities, Social

Sciences and Creative Arts

\title{
ANALYSIS OF PARENT - TEENAGER'S COMMUNICATION ON SEX EDUCATION AMONG SELECTED PARENTS IN ABEOKUTA, OGUN STATE
}

\begin{abstract}
*A.M ARIYO AND T.M. ARIBISALA
D epartment of Home Science and Management, Federal University of Agriculture, A beokuta,

*Comesponding Author:motunrayoariyo@yahoo.com Tel: +2348084623889

ABSTRACT

The study examined the impact of parents - teenagers' communication on sex education. Three research questions were generated for this study. The study utilized a purposive sampling technique to select 246 parents in Abeokuta Metropolis. Results indicated that $59.8 \%$ of parents disagreed to discussing sex education with their children until they are fully matured, $76.8 \%$ of the parents wait for the right mood of their teenagers before giving them sex education and $63.7 \%$ of the parents reported that their teenage child find them boring whenever they want to give them sex education. It was recommended that parents should endeavour to be a friend to their children even before their teen years so as to enable an effective parent - teenagers' communication.
\end{abstract}

Key words: Parents, Teenagers, Communication skills, Sex Education, Communication, Sexuality.

\section{INTRODUCTION}

Sex was reported as a topic too embarrassing to discuss at home in many cultures (Jaccard, Dittus and G ordon 2000; Robert \& al. 2005; Yu 2007a), but parents were identified as the preferred source of sex education when compared with peers, school, media and health professionals, as reported in a US study of 672 pupils (Somers and Surmann, 2004).

Parents have a profound influence on the development of sexual attitudes, beliefs, and behaviours, especially in the years leading to early adolescence (Hecht \& Eddington, 2003). Parents influence teen sexual behaviour in a variety of ways, including modelling, maintaining a warm and close relation- ship that facilitates open communication, monitoring teen activities, and encouraging religious beliefs and practices that influence morality and sexual behaviour (Miller, 2002; National Campaign, 2003; Rozema, 1986; Werner-Wilson, 1998).

Adolescents feel that the sex education they receive in school is inadequate, and they want open discussions on the topic of sex with their parents (Fay \& Yanoff, 2000; National Campaign, 2003). Although parents want their children to be educated about sexuality and adolescents want to learn these facts from parents, there appears to be a disconnection in parent-child communication on the subject. For example, parents think they are providing more sexuality education 
than what is perceived by adolescents, and parents lack knowledge of when and how to initiate sexuality discussions with their children. Parents report feeling inadequately prepared to discuss sexuality in general and think that teens are not sexually active so they have no need for the information (Somers \& G leason, 2001). Simply knowing "what" to discuss may be insufficient: parental openness, skill, and comfort-level mediate the impact of parent-child communication on sexual behaviour (Whitaker, Miller, May, \& Levin, 1999).

Parents report discomfort in addressing certain topics with their children. One study found that parents anticipated feeling uncomfortable discussing abortion, masturbation, and homosexuality and were less likely to talk to their children about these topics compared to other sexuality topics (Koblinsky \& Atkinson, 1982).

In recent times, the rapid rise in sex and sexually related activities among adolescents in Nigeria is quite disturbing and worrisome as lewd expressions and actions within this class seem normal, and even heralded, and often times are seen as "fashionable" (Ayuk, 2012). This, according to Onete, Eyo \& Udey (2009), is because of a disconnect from the home environment, which understandably is supposed to be where a child starts to socialize and to be socialized.

No doubt in the past 30 to 40 years in Nigeria, adolescent sexually-related activities have increased tremendously and reports have it that, male adolescents have had sexual experience by age(s) 18 and females at age(s) 12 to 13. (Cattel, 2006). This state of affairs is not unconnected with lack of parents' attitude towards sexuality education. As it is, parents are expected to equip and expose their children to varied sources of knowledge related to their sexuality. Unfortunately, as observed by O nete $\notin$ al. (2009), the practice of parent's attitudes and sexuality education is grossly bereft in Nigeria. Even parents with requisite exposure and knowledge feel uncomfortable talking to their children at home about the subject, which incidentally is indispensable to the adolescents' sexual life and parents' happiness (Ayuk, 2012).

Preponderance of African culture abhors discussion bordering on sex publicly, rather sex related issues are considered sacred or sacrosanct and not to be discussed in the presence or hearing of the children. This attitude rather than helping, arouses inquisition in the minds of teenagers thereby seeking information from uncontrolled and not wellinformed sources like peer groups, films, magazines etc which in truth pose dire consequences.

During this period of information technology, it would be a mistake for parents to take for granted sex education of their children. Normally, children who are not knowledgeable about their sexual safety display ignorance of their reproductive physiology, sexually transmitted diseases (STD s), and sexual circles (for females), when they are safe and other risk factors not mentioned, associated with sexuality. It becomes even more devastating as some end up so early in the "FAMILY - WAY" i.e. pregnancy and for the males becoming fathers -unexpectedly) Joseph, (2007).

This phenomenon of not discussing sexuality imperatives is not restricted to only the uneducated Nigerians. Even the educated parents do not guide or counsel their children 
ANALY SIS OF PARENT - TEENAGER'S COMMUNICATION ON SEX EDUCATION...

for fear that the children would experiment with sex. (Joseph, 2007)

Unplanned pregnancy and the contraction of sexually transmitted diseases continue to be prevalent problem among adolescents. These problems often result in adverse health, social and economic consequences for teenagers and their families. D iscomfort with this topic of discussion has been identified as a barrier to effective familial sex communication. Although there are several factors that contribute to these problems, effective sex communication between parents and their adolescents has been identified as a key strategy for reducing teen risktaking behaviours (Holtzman \& Robinson, 1995).

Fox and Inazu (2000) found out from various studies that parents were either ignorant themselves, embarrassed to discuss sexual topics, afraid that knowledge will lead to experimentation or set negative example at home.

\section{Research Q uestions}

1. What is the perception of parents towards sex education?

2. How do parents communicate sex education with their teenagers?

3. How receptive are teenagers towards parental sex education?

\section{METHODOLOGY Population and Sampling Procedure}

Random sampling technique was used in the selection of respondents where two local government areas were randomly selected in Abeokuta namely; Abeokuta South and Odeda Local Government Area. The selected respondents in Abeokuta South were 86 and 160 parents in Odeda Local government area which made a total of 246 parents used in this study, with criteria that they are parents to teenagers.

The target population was all parents in Abeokuta, Ogun state.

\section{Instrumentation}

The research instrument was designed by the researcher. The questionnaire elicited information on demographic characteristics of the respondents, perception of parents towards sex education, how parents communicate sex education with their teenagers and how receptive teenagers are towards parental sex education.

\section{Validation of Instrument}

A pilot study was carried out to validate the instrument where the instrument was administered to 30 parents in Lagos. The psychometric properties of each section revealed the following; perception of parents towards sex education had an alpha value of .856, how parents communicate sex education with their teenagers had an alpha value of .888 , how receptive teenagers are towards sex education had an alpha value of .727, which made the instrument to be considered reliable and stable over time and then used for the study.

\section{Data Analysis}

Primary data was subjected to descriptive statistics of frequency counts, percentage, mean and standard deviation.

\section{RE SULTS AND DISCUSSION}

Research Q uestion One: What is the perception of parents towards sex education? The result in Table 1 shows that $69.2 \%$ believe that it is not wrong to discuss sex education with their teenagers. Also, parents in this study did not subscribe to buying general books on sex education for their teenag- 
ers but rather discussing sex education one on one with their teenagers which implies that parents now consider sex education for their teenagers as a paramount necessity and responsibility of theirs which supports the submission that sex is a natural instinct and parents owe the children the responsibility and onus to teach them to learn about sex in dignified ways (Joseph, 2007). About $45.2 \%$ of the respondents agreed that mothers should be the one to give sex education to their teenagers whereby 54.8 disagreed to this as fathers and mothers are jointly required to bring up a child including giving $\mathrm{him} /$ her sex education. Furthermore, 46.3\% agreed that they would arouse the sexual urge of teenagers if they engaged them in sex education, $40.2 \%$ of the respondents submitted that they cannot be discussing sex education with teenagers that are not fully mature which is in line with Somers \& Gleason (2001) who submitted that parents report feeling inadequately prepared to discuss sexuality in general and think that teens are not sexually active so they have no need for the information. This revelation shows a lack of enlightenment on the part of parents on sex education as this should not be delayed for whatever reason as sex education should begin even before children grow to become teenagers as Bene (2006) opines that if children ask questions, parents should not worry about whether they are too young to know the answers, since children understand what they are ready to understand.

Table 1: Perception of parents towards sex education

\begin{tabular}{|c|c|c|c|c|c|c|c|}
\hline $\mathbf{S} / \mathbf{N}$ & Statement & D & SD & $\mathbf{A}$ & SA & Mean & Std.dev \\
\hline 1 & $\begin{array}{l}\text { I believe mothers } \\
\text { should be the ones to } \\
\text { Give sexual education } \\
\text { to their teenagers }\end{array}$ & $56(22.8 \%)$ & 79 (32.1) & $57(23.2 \%)$ & $54(22.0 \%)$ & 2.44 & 1.07 \\
\hline 2 & $\begin{array}{l}\text { I will only arouse the } \\
\text { sexual urge of teen- } \\
\text { ager if I engage them } \\
\text { in sex education }\end{array}$ & $64(26.0 \%)$ & $68(27.6 \%)$ & $79(32.1 \%)$ & $35(14.2 \%)$ & 2.35 & 1.02 \\
\hline 3 & $\begin{array}{l}\text { I cannot be discussing } \\
\text { sex education until my } \\
\text { teenagers are fully ma- } \\
\text { ture }\end{array}$ & $70(28.5 \%)$ & $77(31.3 \%)$ & $78(31.7 \%)$ & $21(8.5 \%)$ & 2.20 & 0.95 \\
\hline 4 & $\begin{array}{l}\text { I will rather buy books } \\
\text { on sex education for } \\
\text { my teenagers rather } \\
\text { than discussing it }\end{array}$ & $93(37.8 \%)$ & $62(25.2 \%)$ & $73(29.7 \%)$ & $18(7.3 \%)$ & 2.07 & 0.98 \\
\hline 5 & $\begin{array}{l}\text { I believe it is totally } \\
\text { wrong discussing sex } \\
\text { education with my } \\
\text { teenage }\end{array}$ & $81(32.9 \%)$ & $89(36.2 \%)$ & $63(25.6 \%)$ & $13(5.3 \%)$ & 2.03 & 0.89 \\
\hline
\end{tabular}


ANALY SIS OF PARENT - TEENAGER'S COMMUNICATION ON SEX EDUCATION...

Research Question Two: How do parents communicate sex education with their teenagers? The results in table 2 indicates that $80.9 \%$ of the parents agreed that they ensure that there is no third party around while talking to their teenagers on sex education. Majority of the respondents $82.1 \%$ agreed to always creating time especially during special occasion to talk about the need for abstinence from sex until marriage to their teenager which does not support the submission of (Madunagu, 2006) that parents should be alert to "teachable moments" and they should use everyday situations and occurrences like watching films to begin conversation about sexuality and to the point; go beyond the obvious, but with caution and stop when it is necessary. Also, $76.8 \%$ agreed that they wait for the right mood of their teenagers before giving them sex education all of which indicates that parents study the mood of the teenagers before they can give them sex education. This implies that parents respect and understand the phase and features of their teenagers and also understand the concept of communication with teenagers as the mood of the teenager would be a strong determinant of the effectiveness of sex education.

About $40.6 \%$ disagreed to freely communicate sex education with their teenage child which leaves more parents freely communicating sex education to their teenagers which negates the findings of Kodagoda (1997) who submitted that parents are reluctant to talk about sex to their daughters as they found it embarrassing to discuss these issues.

Table 2: How parents communicate sex education with their teenagers

\begin{tabular}{|c|c|c|c|c|c|c|c|}
\hline $\mathrm{S} / \mathrm{N}$ & Statement & D & SD & $\mathbf{A}$ & SA & Mean & $\overline{\text { Std.dev }}$ \\
\hline 1 & $\begin{array}{l}\text { I ensure there is no third } \\
\text { party around while talk- } \\
\text { ing to my teenager on } \\
\text { sex education }\end{array}$ & $24(9.8 \%)$ & $23(9.3 \%)$ & $122(49.6 \%)$ & $77(31.3 \%)$ & 3.02 & 0.89 \\
\hline 2 & $\begin{array}{l}\text { I always create time } \\
\text { especially during special } \\
\text { occasion to talk about } \\
\text { the need for abstinence } \\
\text { from sex until marriage } \\
\text { to my teenagers. }\end{array}$ & $30(12.2 \%)$ & $14(5.7 \%)$ & 139 (56.5\%) & $63(25.6 \%)$ & 2.96 & 0.90 \\
\hline 3 & $\begin{array}{l}\text { I watch out for the } \\
\text { mood of my teenager } \\
\text { before giving sex educa- } \\
\text { tion. }\end{array}$ & 46 (18.7\%) & $11(4.5 \%)$ & 98 (39.8\%) & $91(37.0 \%)$ & 2.95 & 1.08 \\
\hline 4 & $\begin{array}{l}\text { I always give practical } \\
\text { examples to illustrate } \\
\text { how teenagers are sex- } \\
\text { ually harassed. }\end{array}$ & $48(19.5 \%)$ & $28(11.4 \%)$ & 94 (38.35\%) & $76(30.9 \%)$ & 2.80 & 1.08 \\
\hline 5 & $\begin{array}{l}\text { I freely communicate } \\
\text { sex education with my } \\
\text { teenage child. }\end{array}$ & $69(28.0 \%)$ & 31 (12.6\%) & $116(47.2 \%)$ & $30(12.2 \%)$ & 2.43 & 1.03 \\
\hline
\end{tabular}


Research Question Three: How receptive are teenagers towards parental sex education? Table 3 indicates that $87.0 \%$ of the respondents agreed that sex education, has really helped their teenage children to understand their limit with the opposite sex, this is not surprising in that early education on sex would help teenagers understand the dangers in careless relationships with the opposite sex which is in line with Marie Stopes International (2008) and Moore \& Rosenthal, (2006) on their views that adolescents whose parents had communicated with them about sex were more likely to delay sex than their peers whose parents had not communicated with them about sex. 59.4\% observed that their teenage chil- dren was always uncomfortable each time they attempt to give sex education and $53.7 \%$ agreed that their teenage children find them boring whenever they want to give sex education which supports the submission of Jaccard $\&$ al., (2000) that reported teenagers feeling hesitant embarrassed or awkward to some extent, about engaging in and initiating talks about sex with their parents. How parents broach the topic of sexuality with their children may affect comfort-levels for both adolescents and parents. Teens want parents to initiate the conversation and to have an interactive or open dialogue rather than be preached to or given unsolicited advice (Fay \& Yanoff, 2000; Pluhar \& K uriloff, 2004).

Table 3: Teenagers receptivity towards parental sex education

\begin{tabular}{lllllll}
\hline S/ N & Statement & D & A & SA & Mean Std.dev \\
\hline 1 & $\begin{array}{l}\text { I observed that sex edu- } \\
\text { cation has really helped } \\
\text { my teenage child to un- } \\
\text { derstand his/ her limit } \\
\text { with the opposite sex. }\end{array}$ & $15(6.1 \%)$ & $119(48.4 \%)$ & $95(38.6 \%)$ & 3.19 & 0.83 \\
2 & & & & & \\
I observed that my teen- $53(21.5 \%)$ & $34(13.8 \%)$ & $76(30.9 \%)$ & $83(33.7 \%)$ & 2.77 & 1.14 \\
age child never asked me \\
questions on sex educa- \\
tion.
\end{tabular}


ANALY SIS OF PARENT - TEENAGER'S COMMUNICATION ON SEX EDUCATION...

\section{CONCLUSION AND RECOMMENDATION}

This study was carried out to analyse parent - teenager's communication on sex education. Findings demonstrated that parents understand the importance and patterns of sex education for teenagers, are informed about the phase and features of teenage years. Also, Sex education has helped teenagers understand their limits with the opposite sex, However, teenagers feel uncomfortable and bored when parents begin sex education. It was recommended that more time be created by parents for sex education, as looking forward to a special occasion before giving sexual education is not appropriate. Also, parents should from the beginning of parenthood foster a healthy parent - child relationship so that when sex education is to be given, they will not feel awkward, embarrassed or accused.

\section{REFERENCES}

Ayuk, A. 2012. "Violent crime Against a Girl Child. A Paper Presented at Etung Student" Forum. Unpublished.

Bene, M. 2006. Women's Health and Empowerment, Speeches, Essays and Lectures. Clear Lines Pudications- Calabar - Nigeria.

Cattel, L. 2006. Sexual Behaviour of Young Adults in Latin America. Psychosocial PespeetivesVol.2, 231 - 252.

Fay, J., Yanoff, J. M. 2000. What are teens telling us about sexual health? Results of the Second Annual Youth Conference of the Pennsylvania Coalition to Prevent Teen Pregnancy. Jaumal of Sex EducationandThea py, 25, 169-177.

Fox, G.L., Inazu, J.K. 2010. Patterns and outcomes of mother-daughter communica- tion upon sexuality. Journal of social issues, 36, 7-29.

Hecht, M., Eddington, E. N. 2003. The place and nature of sexuality education in society. In J. R. Levesque (Ed.), Sexualityedr cation: What addescents' rights require(pp 25-37). New York: Nova.

Holtzman, D., Robinson, R. 1995. Parent and peer communication effects on AIDSrelated behaviour among US high school students. Family Planning Perspectives; 27.

Jaccard, J., Dittus, P. J., Gordon, V. V. 2000. Parent-teen communication about premarital sex: factors associated with the extent of communication. Jaumal of Addescent Re serch 15: 187-208.

Joseph, E. 2007. A Study of the Reproductive Health of the Adolescent. Unpublished M.Sc Thesis, submitted to Graduate School - University of Calabar.

Koblinsky, S., Atkinson, J. 1982. Parental plans for children's sex education. Family Rdations, 31, 29-35.

Kodagoda, N. 2007. Guidelines on family life education from Sri Lnka, world health forum.

Marie Stopes Intemational. 2008 SEX Telling it like it is: A parent-teen insight: Marie Stopes International \& Quantum Research.

Miller, B. 2002. Family influences on adolescent sexual and contraceptive behavior. TheJaumal of Sex Reserm, 39, 22-26.

Moore, S., Rosenthal, D. 2006. Sexuality in adolescence: Current trends. Sussex \& New 
York: Routledge.

Somers, C. L., Gleason, J. H. 2001. Does

National Campaign to Prevent Teen Pregnancy. 2003. With onevice2003: Amaica's adilts and teens saind off abait teen pregneng. Washington, DC: Author.

source of sex education predict adolescents' sexual knowledge, attitudes, and behaviors?

Eduration, 121, 674-681.

Somers, C. L., Surmann, A.T. 2004. Onete, O. Ategwu, Eyo, M., Udey, F. 2009. Parental Attitude and Sexuality Education of Adolescents in Central Cross River State. Nigerian Joumal of Social and Dedep ment Issues V ol.6.

Pluhar, E. I., Kuriloff, P. 2004. What really matters in family communication about sexuality? A qualitative analysis of affect and style among African American mothers and adolescent daughters. Sex Eduration, 4, 303-321.

Robert, A. B., Oyun, C., Batnasan, E., L. Laing. 2005. Exploring the social and cultural context of sexual health for young people in Mongolia: implications for health promotion. Social Saience\& Mediane60: 1487 -98 .

Rozema, H. J. 1986. Defensive communiSources and timing of sex education: relations with American adolescent sexual attitudes and behaviour. Edurational Review 57: 37-53.

Wemer-Wilson, R. J. 1998. G ender differences in adolescent sexual attitudes: The influence of individual and family factors. Ado lescence, 33, 519-532.

Whitaker, D. J., Miller, K. S., May, D. C., Levin, M. L. 1999. Teenage partners' communication about sexual risk and condom use: The importance of parent-teenager discussions. Family Planning Pespeetives, 31, 117121.

Yu, J. 2007a. School sex education: views within British-Chinese families. Asian Jaumal of Nursing10: 171-8.

cation climate as a barrier to sex education in the home. Family Rdations, 35, 531-537.

(Manusaipt recived: 13thAugust, 2017; accepted: 21stJune, 2019). 